\title{
Management of Public Services in the Library and Archival Office of West Nusa Tenggara Province
}

\author{
Lalu Kamarudin; Agil Al Idrus; Joni Rokhmat \\ Master's Program in Education Administration, Postgraduate Program of Mataram University, Indonesia
}

http://dx.doi.org/10.18415/ijmmu.v8i9.2890

\begin{abstract}
This research aims to find out the management of public services and how to improve public services in the Regional Library and Archival Office of West Nusa Tenggara Province. This study uses descriptive qualitative methods. In this research, data collection techniques using interviews, observations, and documentation of public services in the Regional Library and Archival Office of West Nusa Tenggara Province. Data analysis techniques are performed with data reduction measures, data presentation, and conclusion drawing. In this research, data validity check techniques using credibility, transferability, dependability, and confirmability. The results show that: (1) public service management ranging from planning, organizing, implementation, and evaluation is still fully not running smoothly. Public services provided have been very maximal, although, in its implementation, there are still perceived shortcomings ranging from lack of reading collection materials, inadequate infrastructure, minimal funds, and the need for building procurement to support the implementation of existing services so that services to the community are still felt less; (2) Efforts of NTB Provincial Library and Archival Office to improve and improve public services conducted by always improving human resources and improving infrastructure facilities to support the implementation of public services.
\end{abstract}

Keywords: Management; Public Service

\section{Introduction}

People desperately need the information to add knowledge gained from formal and informal education. One of the infrastructure facilities to obtain information is the implementation of infrastructure facilities such as libraries. The library was developed and disseminated evenly to help the implementation and improve the quality of education. It is expected that the public can obtain good information from the library and use the information to improve themselves.

Government Regulation No. 24 of 2014 has explained that libraries that are basically information management, information management in question are collecting, compiling, and maintaining books and library documents to provide knowledge needs. Good library management can not be separated from the management contained in it. An institution is said to be good when it has good management and organization. Basically, management is an activity to achieve the goal through a planned, organized, carried out and evaluated process.

Library management is the process of utilizing human contributions, materials, budgets to achieve organizational goals managed based on management principles (Anwar et al. 2019). Library management is based on the process of maintaining, storing, and collecting a collection of regularly managed 
bibliography using human resources used for information. The achieving the objectives of the vision, the library's mission needs to develop the management aspects contained in it there are aspects of service. The service aspect is very important in every management because it relates to customers, the community that demands satisfaction in the management.

The demands of the community will be fulfilled the rights and obligations as recipients of services, and then it should be the services provided must be in accordance with the needs of the visitors. It is also stated in Government Regulation No. 96 of 2012 concerning public services states that the State is obliged to serve every citizen and resident to meet the needs of rights and basics in the framework of public services, which is the mandate of the Constitution of the Republic of Indonesia 1945. Public service is an activity or series to fulfill the needs of services according to the laws and regulations for every citizen and resident of goods, services, and or administrative services provided by public service providers.

The Library and Archival Office of West Nusa Tenggara Province (NTB) is an institution that implements education services in improving the quality of education with excellent accreditation. The various services available include reference services, circulation services, information services, and digital library services. The existence of various kinds of services should make the visitors satisfied and can get what they want, but the lack of attention from the service makes library visitors complain about the limitations of references and services that exist and do not correspond to the big-name provincial library number one in NTB, this library should be able to provide a variety of references and good services.

\section{Method}

This study uses descriptive qualitative. Data collection in this study was conducted through observation activities, interviews, and documentation. Observation focuses on the management activities of service management conducted by NTB regional library staff, paying attention and recording all activities in the public service process. Observations are made on a scheduled basis according to the time specified.

Interviews in research are conducted with all predetermined informants in order to collect data on public service management. It is expected that with this structured and unstructured interview, researchers can ask questions available in the interview guidelines but can dig up other information related to the focus of the research to be researched.

The documentation collected in this study is written data on public service archives, visitor data, as well as records of maintenance and procurement of service equipment that supports public service management. Researchers use two types of source triangulation techniques and triangulation methods in conducting interviews, observations, and documentation. The process of testing the validity of the data in this study is determined by measures of credibility, transferability, dependability, and confirmability.

\section{Result and Discussion}

\section{Public Service Management of Ntb Provincial Library and Archival Office}

\section{Planning}

The purpose of the planning is to determine the objectives, policies, procedures, and programs that are effective in addressing service problems at the Ntb Provincial Library and Archival Office. In accordance with the planning objectives described by Handoko (2014) explained that planning is an effort 
or effort to reduce uncertainty by using planning as a director in carrying out the task is expected to be well organized and achieve the expected goals. So with the planning can know the needs and steps that must be carried out with directed to overcome public service complaints Ntb Provincial Library and Archival Office. To overcome the problems felt by the service planning and developing the service process, the planning that has been done is the program of filling form, mobile library, and door to door.

\section{Organizing}

According to Saondi (2014) explained that organizing is a step to develop and can carry out the planned program by determining the resources, assignments, and responsibilities to carry out the tasks that have been given. The organization of human resources in the Regional Library and Archival Office of NTB Province does not conduct special selections or qualifications in filling the tasks or positions given because it prioritizes cooperation and filling each other. In one area of service, all staff must help each other maximize the services provided in accordance with the duties and functions.

\section{Implementation}

From the program that is run, there are still constraints felt by the service, the problem has been from the past, and there has never been a serious response to overcome the problem. The problem that continues to occur is the lack of book collection in the Regional Library and Archival Office of NTB Province. The lack of collection materials becomes a monotonous problem felt by the user and the service. The results of interviews with the head of field and service staff confirm that the existing book collection is very lacking, and there needs to be an addition of collections to expand further, and the choice of reading materials is increasingly diverse. The problem continues to occur over and over again. So the service does not have a solution for procurement because the available funds are still limited. But from the service always provide maximum service so that the program can run and use existing materials and infrastructure.

\section{Evaluation}

Evaluation is done on institutions and library programs that have been done and can be evaluated by the library organizers and interested parties. Evaluation is conducted in sequence from subordinates to superiors. The leadership applies reports to staff on the responsibilities of the perform performed. Based on the observation of the form of performance is reported through the daily report to know the activities and work carried out by the staff are appropriate or not. With the report, the leaders can know and evaluate the performance of the staff. From the daily report, the public service expects there to be improved performance and discipline carried out so that the services provided to the community can be maximized. In addition to staff performance assessment, assessment and evaluation of the program that has been run are also carried out by the service. Evaluation of the program is conducted directly in the field, with visits and monitoring in the field conducted by stakeholders by the time specified. All forms of complaints and findings in the field are used as a report to be followed up by policymakers.

\section{How to Improve Public Service Management in NTB Provincial Library and Archival Office}

\section{Human Resources}

In realizing the organization's objectives are needed quality resources, with good resources greatly affect the results of the performance of the staff. In the sense that an organization will succeed if the employees are able to contribute and support the entire process of activities carried out. Siagian (2014) explained that seven benefits could be obtained from human resources development, including (a) Increase work productivity; (b) The realization of a harmonious relationship between superiors and subordinates; (c) The occurrence of the retrieval process faster and more precisely; (d) Increase the morale of the entire workforce; (e) Encourage openness; (f) Facilitate the process of formulating 
organizational policy and its operationalization; (g) Functional conflict resolution, whose impact is the proliferation of a sense of unity and kinship of the members.

NTB provincial library and archival office have adequate resources, but with the existing resources, the library, especially the public service sector, should not be satisfied with the capabilities and performance of the current staff. There needs to be self-awareness by putting forward attitudes and responsibilities as librarians. With the improvement of human resources, the library, especially public services, provides learning, training, and seminars to the staff to adjust to the demands of the task so that the performance of the staff can be improved and adjust to the career path. Handoko (2014) explained the importance of employee mentoring training to reduce and eliminate inappropriate work habits and learn new skills that can increase employees' potential. With that, the library is always improving and improving the resources owned by training, development, and learning conducted continuously between senior staff and junior so that the results of the improvement of human resources has an impact on improving the services provided by service staff in the Library and Archives of NTB Province.

\section{Facilities}

Library infrastructure facilities are a very important need and must be met. Facilities and infrastructure facilities are an attraction for visitors and also the library officials themselves. Infrastructure facilities owned by the Regional Library and Archival Office of NTB Province are still considered very lacking. The room's condition and existing infrastructure interfere with the smooth work of the employees and the comfort of the visitors. With the fulfillment of infrastructure facilities, it will create comfort for visitors and employees themselves. So that with the improvement of infrastructure facilities carried out, employees will be more comfortable in working and attracting library visitors.

Library management is not solely based on theory but, most importantly, how the theory is carried out, management consisting of planning, organizing, implementation, and supervision must be carried out to achieve the objectives of an organization. Sutarno (2006) explained that to achieve library management must be supported by management elements including (1) Man, (2). Money, (3) Supporting machine, (4) Material, (5) Mechanism of action, 6). Where transactions or services take place, the management element is a resource that must be managed properly in order to organize a quality library, as good as management is able to manage and meet the elements of management, so that public service management can run well with the fulfillment of the needs of the community. The findings of this study explain that not only the management process in general that needs to be implemented for the advancement of public services but the fulfillment of management elements to complete the implementation of public service management such as people, money, supporting machines, materials, mechanisms of action, where transactions or services take place.

Finally, this research can be concluded that in an organization of pulik services, maximum service and quality are needed so that the community is satisfied with the services provided. To get the maximum service results can not be done with planning management, organizing, implementation, and evaluation alone, but must be supported by the fulfillment of existing human resources to carry out the management process with the knowledge and skills possessed. In addition to human resources, it must be supported by adequate funds and infrastructure facilities; with adequate funds and infrastructure facilities, the process of activities will run smoothly because the needs of the community for services are based on infrastructure facilities obtained through large funding. So that the shortcomings felt by the community will be quickly resolved by the service with the number of funds available. The importance of human resources, funds, facilities, where the service must be realized so as to give a very significant impact on the success of public services. 


\section{Conclusion}

Based on the results and discussions can be concluded that: (1) The management of public services of the NTB Provincial Library and Archival Office ranging from planning, organizing, implementing, and evaluating is still fully not running to the maximum due to inadequate infrastructure facilities, minimal funds and the need for building procurement to support the implementation of existing services; (2) The efforts of NTB Provincial Library and Archival Office to improve and improve public services are carried out by improving the human resources and improving infrastructure facilities to help maximum service and create comfort from the staff and visitors of the library.

\section{References}

Anwar. A., Maskur, M., Jaelani. J. (2019). Manajemen Perpustakaan. Riau: PT. Indragiri.

Presiden Republik Indonesia. (2012). No 96. Pelayanan Publik : Jakarta.

Handoko, H. (2014). Manajemen Personalia dan Sumber daya Manusia. Yogyakkarta: BPFE.

Presiden Republik Indonesia. (2014), No 24. Undang-Undang Perpustakaan: Jakarta.

Saondi, O. (2014). Membangun Manajemen Pendidikan. Bandung: Refika Aditama.

Siagian, S. (2014). Manajemen Sumber Daya Manusia. Jakarta: Bumi Aksara.

Sutarno, N.S. (2006). Manajemen Perpustakaaan. Jakarta: Sagung Seto.

\section{Copyrights}

Copyright for this article is retained by the author(s), with first publication rights granted to the journal.

This is an open-access article distributed under the terms and conditions of the Creative Commons Attribution license (http://creativecommons.org/licenses/by/4.0/). 